\title{
Epidemiological, Clinical and Computed Tomographic Profile of Conjunctival Epidermoid Carcinoma: About 54 Cases
}

\author{
N. S. Déde, E. V. Acko-Ohui*, L. N. Gui-Bilé, K. E. Kouadio, R. M. Kabas, L. M. A. Diambra, P. Yapo \\ Department of Radiodiagnostics and Imaging, University Hospital of Treichville, Abidjan, Cote d'Ivoire \\ Email: *ohuiestelle@yahoo.fr
}

How to cite this paper: Déde, N.S., Acko-Ohui, E.V., Gui-Bilé, L.N., Kouadio, K.E., Kabas, R.M., Diambra, L.M.A. and Yapo, P. (2018) Epidemiological, Clinical and Computed Tomographic Profile of Conjunctival Epidermoid Carcinoma: About 54 Cases. Open Journal of Radiology, 8, 293-298.

https://doi.org/10.4236/ojrad.2018.84032

Received: November 6, 2018

Accepted: December 3, 2018

Published: December 6, 2018

Copyright $\odot 2018$ by authors and Scientific Research Publishing Inc. This work is licensed under the Creative Commons Attribution International License (CC BY 4.0).

http://creativecommons.org/licenses/by/4.0/

\begin{abstract}
Conjunctival squamous cell carcinoma is a common malignant tumor in adults. It affects the peri-limbic conjunctiva. This is a neoplasia that is increasing in tropical Africa because it occurs in subjects with prolonged exposure to ultraviolet rays, in patients immunocompromised to the human immunodeficiency virus and HPV infection. Computed tomography allows one to make a diagnosis. We report the case of 57 patients in whom the diagnosis was made radiologically and confirmed by histology.
\end{abstract}

\section{Keywords}

Squamous Cell Carcinoma, Peri-Limbic Conjunctiva, Neoplasia, CT

\section{Introduction}

Conjunctival squamous cell carcinoma is a rare tumor affecting the peri-limbic conjunctiva [1]. It is a malignant tumor that is common in adults [2]. Conjunctival squamous cell carcinoma occurs in patients with prolonged exposure to ultraviolet light, immunocompromised human immunodeficiency virus (HIV) and HPV (human papilloma virus) infections [3]. In the tropics, benign tumors are common such as pterygium. These benign tumors develop on the conjunctiva of the inter-palpebral area, at the level of the limb and tend to invade the cornea [4]. Malignant tumors are much rarer, but must always be present in the mind of the ophthalmologist. The most represented is conjunctival squamous cell carcinoma (SCC), which is one of the differentiated squamous tumors [4], hence it is the interest of this study.

It is an increasing neoplasia in tropical Africa because of these different risk factors. Imaging, especially CT, is still part of the diagnosis and management of 
squamous cell carcinoma. We report the epidemiological, clinical and calculated tomography of this condition in 54 patients.

\section{Patients and Methods}

This was a retrospective study with a descriptive aim carried out over 8 years from February 2008 to February 2017 in the Ophthalmology, Radiodiagnostics and Imaging departments of the University Hospital of Treichville. It involved 54 eyes of 54 patients. Included were all patients who had consulted during the study period and had conjunctival tumor with or without locoregional and cerebral invasion with a histological diagnosis of squamous cell carcinoma. The specific objectives of this study were to describe the epidemiological, clinical and computed tomographic features of conjunctival squamous cell carcinoma in our patients. It also consisted of showing some correlation between the HIV-AIDS virus and this condition.

A clinical examination of the eyes has been performed in all our patients. They all benefited from a computed tomography scan that showed the tumor. A biopsy or surgical excision of the tumor was performed under general anesthesia for anatomopathological analysis. HIV-AIDS serology was performed after informed consent from patients with, in some cases, CD4 cell typing.

\section{Results}

We objectified more women than men with a sex ratio of 0.89 . The age of the patients ranged from 6 to 70 years with an average of 45.5 years. All our patients were black and lived in Abidjan, Côte d'Ivoire (sub-Saharan Africa). The clinic was dominated by orbital tumors with exophthalmia and a conjunctiva-limbic tumor. The damage involved the right eye in all our patients.

HIV serology was positive in 39 patients. Lymphocyte typing was performed in all these patients. From a radiological point of view, the tumor was located in the left eye in 45 patients and in the right eye in 09 patients without intracerebral extension (Figure 1). It was an intraocular burgeoning tissue process with intra and extra conical involvement in all patients (Figure 2).

The optic nerve was stretched in 10 patients. The oculomotor muscles were infiltrated by the tumor in 22 patients (Figure 3 ). There was osteocondensation in contact with the tumor in 38 patients (Figure 4). The diagnosis of squamous cell carcinoma was established after biopsy by tumor incision or surgery. Patients underwent tumor resection combined with adjuvant topical chemotherapy. Postoperative follow-up was simple in all patients. These different variables studied are summarized in Table 1.

\section{Discussion}

Conjunctival squamous cell carcinoma occurs most often in the elderly [4]. All reported patients had an age ranging from 6 to 70 years with an average of 45.5 years. Chronic irritation of an infectious nature, such as trachoma, or mechanical, 


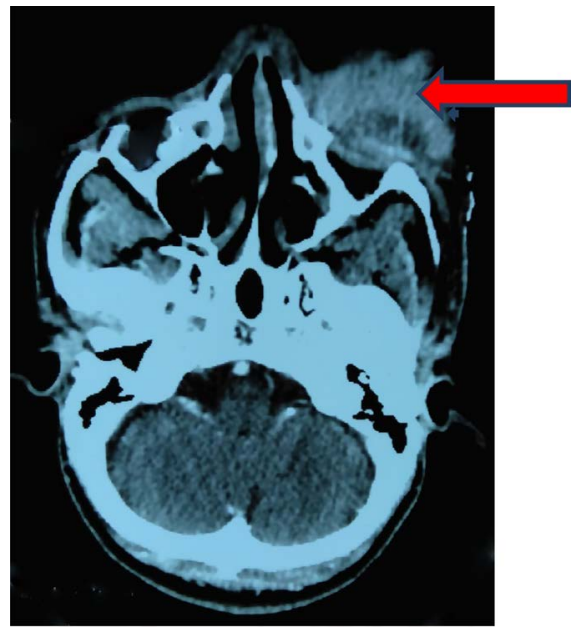

Figure 1. Axial CT scan parenchymal window: left intraorbital budding tumor process.

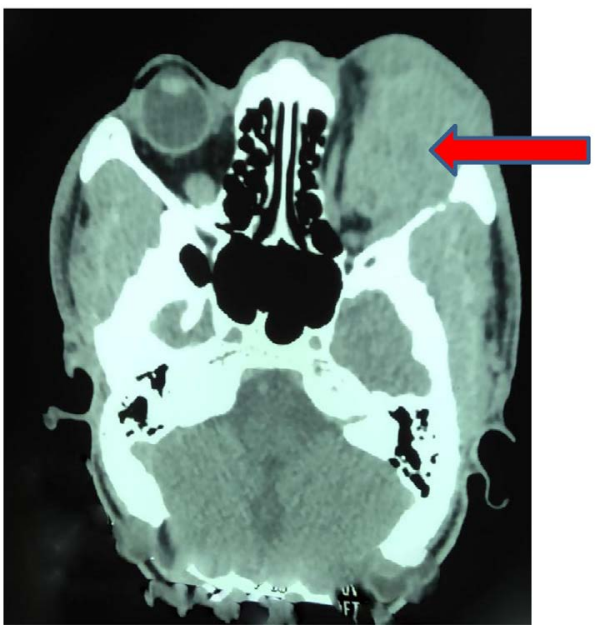

Figure 2. Axial CT scan parenchymatous window: intranibular left mass with intra and extra conical extension (horizontal arrow). Presence of another tumor process beginning in the right eye (curved arrow).

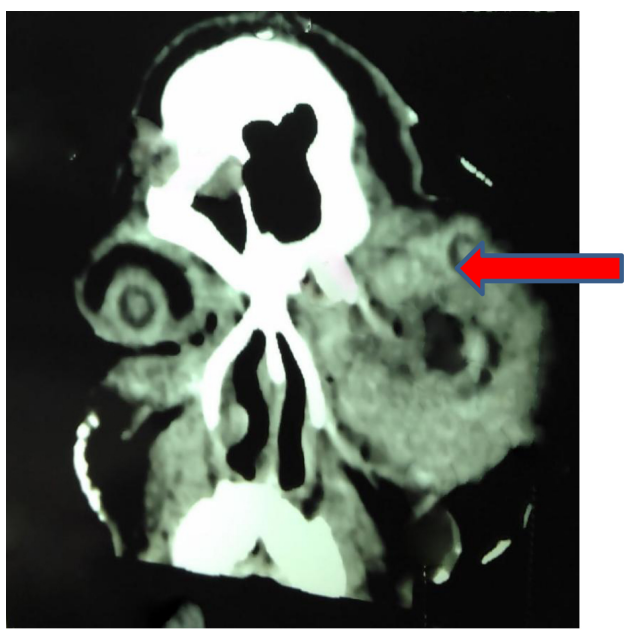

Figure 3. Axial CT scan parenchymatous window: intra-orbital left mass with intra and extra conical extension. 


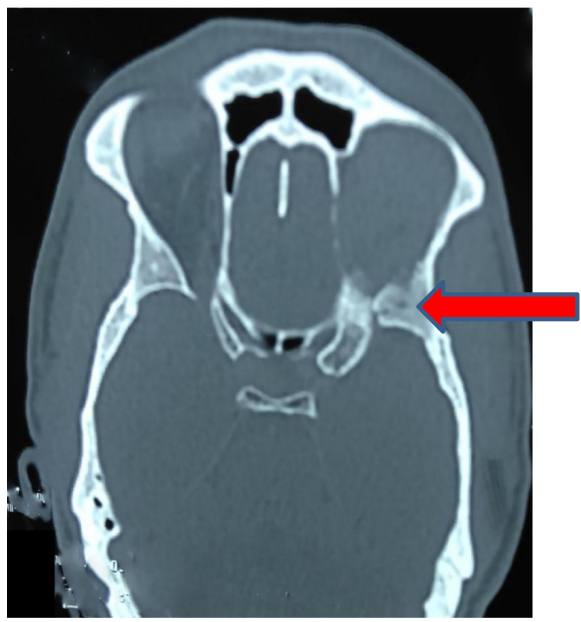

Figure 4. CT scanographic axial view of the bone window: osteocondensation of the left zygomatic process.

Table 1. Abstract table of the variables studied.

\begin{tabular}{cc}
\hline VARIABLES STUDIED & RESULTS \\
\hline SEXE dominant & 48 hommes \\
Average age & 45.5 years \\
RESIDENCE & All in Ivory Coast \\
Serology HIV & 39 patients \\
Main site of tumor & Left eye in 45 patients \\
Clinical & Clinical orbital and conjunctiva limbic tumors \\
Optic nerve damage & 10 patients \\
Occultomotor muscle damage & 22 patients \\
Osteocondensation & 38 patients \\
Treatment & tumor resection + adjuvant topical chemotherapy
\end{tabular}

such as dust, and infection with Human Papilloma Virus (HPV) 16 or 18, would be risk factors [5].

No ethnological factor has been identified. When conjunctival squamous cell carcinoma occurs at earlier ages, HIV infection should be sought. HIV is not directly carcinogenic: it is a promoter in the development, extension and distribution of these tumors. HIV induces a chronic suppression of the immune system, hence the anti-cancer immunity, which increases the oncogenic potential in case of dysplasia [6]. More than half of our patients had HIV. This confirms the correlation between HIV and the occurrence of conjunctival squamous cell carcinoma.

Cutaneous squamous cell carcinomas are exceptional in the melanoderm population [4] [5]. Our study shows that this population is not spared by this tumor because all our patients were black. Prolonged sun exposure is unanimously recognized as a predisposing factor for corneo-conjunctival dysplastic lesions, 
precancerous and by extension to Conjunctival squamous cell carcinoma [7]. Ultraviolet rays are harmful on the epibulbar conjunctiva opposite the palpebral closure slot straddling the limb [7]. Conjunctival squamous cell carcinoma can occur in different clinical forms [8]: the most common is the gelatinous form, characterized by dilated superficial vessels. The nodular form has an increased lymph node metastatic potential. It was the nodular form presented by all our patients.

Imaging, in particular CT, can be used to assess the lesion of the tumor [2] [9]. It was a burgeoning, ulcerated tumor infiltrating intra and extra conical fat. Computed tomography showed the extension of the tumor to the occulomotor muscles in some and stretching of the optic nerve in others. The extension was also at the optical chiasma level in some of our patients which explained the blurred vision in these patients. The tumor may extend in some cases in the cerebral parenchyma. In our case, we did not have intra-parenchymal cerebral extension. On the other hand, there was bone involvement such as osteocondensation of the affected orbital walls. Lymph metastases (pre-vaginal and sub-angulomaxillary) and general metastases (heart, lung, brain) are rare and mainly concern highly evolved tumors [10].

Histology alone allows diagnosis with certainty [11]. Conjunctival squamous cell carcinoma consist of atypical epithelial cells organized in spans or isolated and located within concentric dyskeratotic cells, forming horny globes. The limbus of the conjunctiva is an area favorable to the hatching of the precancellous and cancerous lesions because of the presence of the deposit of the compartment of the stem cells, origin admitted of the essential of the renewal of the corneene epithelial coating. It is indeed in this region that most carcinomas

Histological analysis was performed in all our patients after an incision or surgical excision.

The treatment is mainly based on surgery associated with chemotherapy. Adjuvant external radiotherapy or contact may also be proposed in infiltrating ECCs to avoid the risk of local recurrence and swarming of cancer cells at the level of the operating site [12]. In our case, it was performed surgery and chemotherapy in all our patients [12]. In our patients, surgery and chemotherapy were performed.

\section{Conclusions}

Conjunctival squamous cell carcinoma is a common malignant tumor in adults. The risk factors involved are HIV infection, prolonged exposure to ultraviolet radiation and HPV infection (human papilloma virus). Our study confirms the link between conjunctival squamous cell carcinoma and HIV/AIDS.

Conjunctival squamous cell carcinoma has a poor prognosis and is a public health problem because of its late management. Imaging including CT is of paramount importance in the positive diagnosis and the extension assessment.

Histology is the only test to make the diagnosis of certainty. The treatment 
combines surgery, chemotherapy more or less associated with radiotherapy.

\section{Conflicts of Interest}

The authors declare no conflicts of interest regarding the publication of this paper.

\section{References}

[1] Berete, C.R., Desjardins, L., Kouassi, L.J., Coulibaly, F., Kouakou, K.S., Gbe, K. and Fanny, A. (2016) Relation entre le virus de l'immunodéficience acquis (VIH-sida) et carcinoma épidermoïde conjonctival (CEC): Etude épidémioclinique de 26 dossiers au service d'ophtalmologie du CHU de Treichville (Abidjan-Côte d'Ivoire). Journal Français d Ophtalmologie, 39, 467-473. https://doi.org/10.1016/j.jfo.2015.09.016

[2] Ogun, G.O., Ogun, A.O., Bekilrele, C.O. and Akang, E.E. (2009) Intraepithelial and Invasive Squamous Neoplasms of the Conjunctiva in Ibadan, Nigeria: A Clinicopathlogical Study of 46 Cases. International Ophthalmology, 29, 401-409. https://doi.org/10.1007/s10792-008-9257-8

[3] Biswas, J. and Sudharshan, S. (2008) Anterior Segment Manifestations of Human Immunodeficiency Virus/Acquired Immune Deficiency Syndrome. Indian Journal of Ophthalmology, 56, 363-375. https://doi.org/10.4103/0301-4738.42412

[4] Acis, D., Donnio, A., Ayeboua, L., Richer, R., Guyomarch, J., Warter, A., et al. (2008) Carcinome épidermoïde conjonctival: A propos de 4 cas aux Antilles. Journal Français d Ophtalmologie, 31, 533-537. https://doi.org/10.1016/S0181-5512(08)72472-0

[5] Shields, C.L., Ramasubramanian, A., Mellen, P.L. and Shields, J.A. (2011) Conjunctival Squamous Cell Carcinoma Arising in Immunosuppressed Patients (Organ Transplant, Human Immunodeficiency Virus Infection). Ophthalmology, 118, 2133-2137. https://doi.org/10.1016/j.ophtha.2011.04.001

[6] Verma, V., Shen, D., Sieving, P.C. and Chan, C.C. (2008) The Role of Infectious Agents in the Etiology of Ocular Adhexal Neoplasia. Survey of Ophthalmology, 53, 312-331. https://doi.org/10.1016/j.survophthal.2008.04.008

[7] Poso, M.Y., Mwanza, J.C. and Kayembe, D.L. (2000) Malignant Tumors of the Eye and Adnexa in Congo-Kinshasa. Journal Français D' Ophtalmologie, 23, 327-332.

[8] Ateenyi-Agaba, C. (1995) Conjunctival Squamous-Cell Carcinoma Associated with HIV Infection in Kampala, Uganda. Lancet, 345, 695-696.

https://doi.org/10.1016/S0140-6736(95)90870-6

[9] Wadell, K.M., Lewallen, S., Lucas, S.B., Ateenyi-Agaba, C., Herrington, G., et al. (1996) Carcinoma of the Conjunctive and HIV Infection in Uganda and Malwi. British Journal of Ophthalmology, 80, 503-508. https://doi.org/10.1136/bjo.80.6.503

[10] Dalton-Griffin, L. and Kellam, P. (2009) Infectious Causes of Cancer and Their Detection. Journal of Biology, 8, 67. https://doi.org/10.1186/jbiol168

[11] Kaimbo Wa Kaimbo, D., Parys-Van Gingerdeuren, R. and Missoten, L. (1998) Conjunctival Squamous Cell Carcinoma and Intraepithelial Neoplasia in AIDS Patients in Congo-Kinshasa. Bulletin de la Societe belge d ophtalmologie, 268, 135-141.

[12] Caujolle, J.P., Maschi, C., Chauvel, P., Herault, J. and Gastaud, P. (2009) Surgery and Addition Nelprotontherapy for Treatment of Invasive and Recurrent Squamous Cell Carcinomas: Technique and Preliminary Results. Journal Français d Ophtalmologie, 32, 707-714. https://doi.org/10.1016/j.jfo.2009.10.016 